\title{
EFFECT OF STOCKING DENSITY, PROTEIN LEVEL AND FREQUENCY OF. FEEDING ON SURVIVAL, GROWTH AND PRODUCTION OF TILAPIA
}

\author{
F.H." El-Sagheer ', M.A. Zaki ', A. M. Nour ${ }^{1}$, A.R. Abou Akkada ${ }^{1}$ and A.M Abd El
Halim $^{2}$ \\ 1- Department of Animal and Fish Production, Faculty of Agriculture, Alexandria University, \\ Governorate, Egypt
}

\section{SUMMARY}

Survival, growth and production of tilapia monosex (mean wt. $20.0+5 \mathrm{~g}$ ) were evaluated whien reared in iwenty four carthen ponds $\left(1500 \mathrm{~m}^{2}\right)$ provided with continuos watcr current with increising fed with two levels of protein $\left(25\right.$ or at three different stocking densities $\left(5,10\right.$ and $\left.15 \mathrm{fish} / \mathrm{m}^{3}\right)$ and experiment duration was 232 days. $32 \% \mathrm{CP}$ ) under two feeding frequencies ( 3 or 6 times/day). The

density or protein level while it increarved wal (\%) was significantly $(\mathrm{P}>0.05)$ decreased with increasing

Growth performance (fimal body with increasing feeding frequency.

rate \%) were significantly ( $P>0.05$ ) decreast, weight gain, average daily gain and specific growth increasing protcin level and frequency of fecding.

Production (Ton ace increas of fecding.

evel and focding frequency.

It was concluded that

were the optimum treatments for production of tilapia monosex in and 6 times of fecding frequency

Keywords: Tilapia (monosex), stocking density, protein level, feeding frequency, survival \%, growth
performance, production

\section{INTRODUCTION}

Tilapia (Oreochromis niloticus) are widely cultured in the tropical and subtropical regions. (FAO, 1980). The choice of breeds for aquaculture is particularly important for tilapia since a number of in tilapia species to pradeces and hybrids are potential candidates (Wolfarth and Hulate, 1983). Sex reversal problem of overpopulation caused by the unconter one of the successful methods for overcoming the sex reversal produce fast-orowing all uncontrolled reproduction in culture ponds. Also, hormonal attained in a shorter time and abtain ale population, so that the desired marketable size can be studies on the relation of stocking density, more uniformed fisls yield after growth in ponds. Numerous out (Hickling 1962; Van der Lingen 1967; Shell 1968). Zonth of tilapia in ponds have been carried of different slocking densities on (phenotypically Oreochrowis nilot Fadholi (1991) studied the effect slowed that growth performance and nutrients utilization wiloticus) reared in ponds. Their results density, however total production increased with incrization were decreased by increasing the stocking

For maximum growtl. of fish, an with increasing stocking density within certain limits.

level of dietary protein does not an optimum protein content in feed is necessary. But the optimum high cost of the protein component of the diead to the most economical production of fish due to the is considered the least requirement the diet. Thus. in Egypt. fish dicts contain $17 \%$ protein and this determined by several investigators and thia. The optimum protein requirenent for tilapia has been (Wang et al, 1985), 30-35\% (Mazid and the results are not consistent. For instance, estimates of $30 \%$ has been reported.

Tilapias, like meals. Kubaryk (1980) found that Nile tilapia grew faster species, benefit from multiple daily feeding times, but did not grew faster when fed eight times. frequency on survival, growth performance and prect of protein level stocking density and feeding ponds. 


\section{MATERIALS AND METHODS}

The experiment was conducted in a randomized complete block design in twenty-four earthen ponds with an average area of $1500 \mathrm{~m}^{2}$

The experiment consisted of three treatments, the first (three stocking densities: $5,10,15 \mathrm{fish} / \mathrm{m}^{3}$ ) the second treatment (two levels of protein: 25 and $32 \% \mathrm{CP}$ ) and the third treatment (two frequencies of feeding 3 and 6 times/day). Two duplicates were made for each sub-treatment. The treatments were assigned to the experimental units completely at random. Twenty percent of water volume in all earthen ponds were partially replaced daily and each pond was continuously supplied all night with paddle wheel air.

Fish were weighed at the beginning of the experiment and every month then after during the experimental period ( 232 days).

Composition of the experimental diets containing 25 and $32 \%$ crude protein is shown in Table 1 . Fish samples were taken at the beginning and at the end of the experiment. The fish flesh of the frozen samples were obtained and based througl a neat grinder into one composite homogenate per group. Content of homogenized fish were analyzed for protein, lipid, moisture and ash according to the procedure of the AOAC (1984).

Table 1. Formulation and proximatc chemical analysis of two diets containing different levels of dietary protein and energy

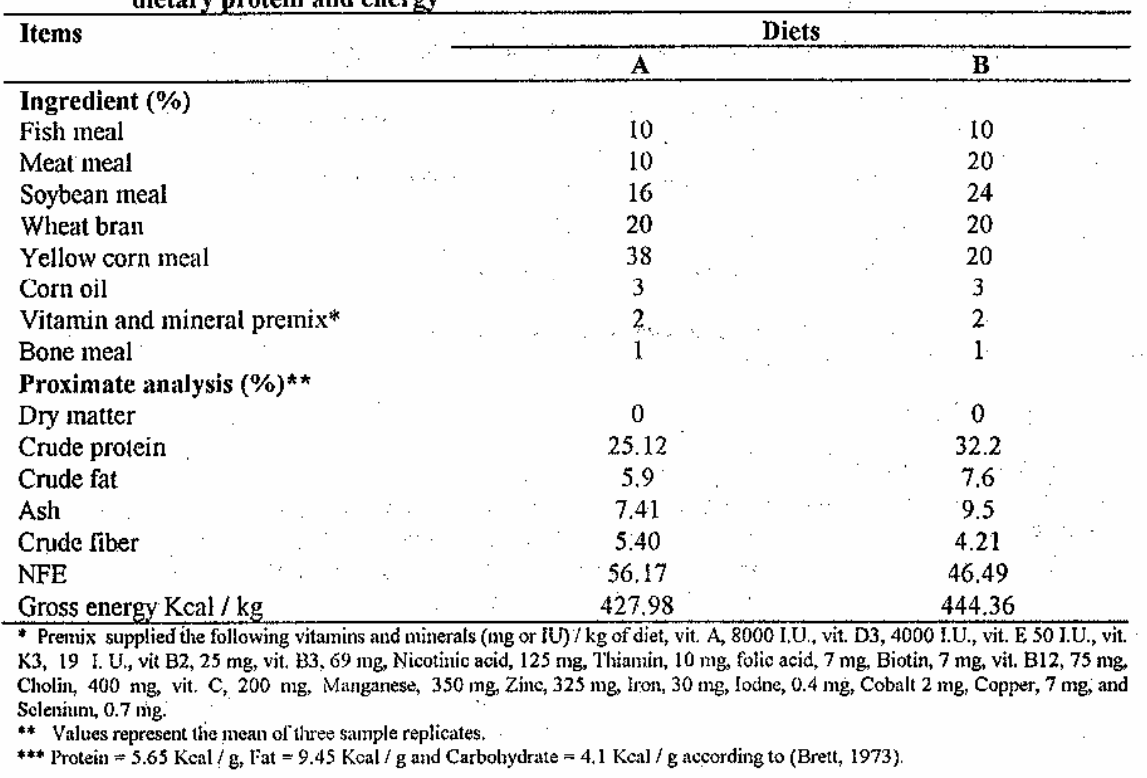

During the 232 feeding trial, water quality parameters were: water temperature $27.4+0.8 \mathrm{C}^{\circ}$, dissolved oxygen $7.6 \pm 0.5 \mathrm{mg} / \mathrm{L}$, total ammonia, $0.16 \pm 0.14 \mathrm{mg} / \mathrm{L}$, nitrite, $0.05 \pm 0.03 \mathrm{mg} / \mathrm{L}$, total alkalinity, $180 \pm 28 \mathrm{mg} / \mathrm{L}, \mathrm{pH} 8.2 \pm 0.16$

Mean of growth performance and feed utilization parameters were calculated as indicated by ZeinEl Dain and Meyers (1973). Gross energy was calculated according to Brett (1973).

Data were analyzed by analysis of variance (ANOVA) using the SAS ANOVA procedure (statistical analysis system. 1988). Means were comparcd according to Duncan's multiple range test (Duncan, 1955).

\section{RESULTS AND DISCUSSION}

Final mean weight was inversely proportional to stocking density, which was particularly evident when average weight of fish held at the lowest and highest densities were compared. However, the 
average weight of fish reared at the lowest stocking density was significantly different from weight of fish reared at the higher densities. In the present study, mean individual fish weights at harvest were significantly higher $\left(\mathrm{P}<0.05\right.$ ) for fish stocked at 5 fish $\mathrm{m}^{-2}$ (average 324.84) than those stocked at 10 or 15 fish $\mathrm{m}^{-2}$ (average $238.68 \mathrm{~g}$ and $228.29 \mathrm{~g}$ respectively), (Table 2). Similar results were obtained by Cruz and Ridh (1991) who showed that the final mean weight was heaviest at low density when tilapia hyprid reared at different densities. On the other hand the growth perfornance in terms of gain, average dialy gain $(\mathrm{ADG})$ and specific growth rate (SGR\%) were affected significantly by stocking density while no significant effect on protein level and feeding frequency on growth performance was detected (Table 2).

Table 2. Means of final weight, growth gain, average daily gain and specific growth rate of mono sex Tilapia reared in ponds

\begin{tabular}{lcccc}
\hline Main effect & Final weight $(\mathrm{g})$ & \multicolumn{3}{c}{ Growth performance } \\
\cline { 3 - 5 } & & $\begin{array}{c}\text { Gain } \\
(\mathrm{g})\end{array}$ & $\begin{array}{c}\text { ADG } \\
(\mathrm{g} / \mathrm{d})\end{array}$ & $\begin{array}{c}\text { SGR } \\
(\%)\end{array}$ \\
\hline Stocking Density: & & & & $1.34^{\mathrm{a}}$ \\
5 & $324.84^{\mathrm{a}}$ & $304.84^{\mathrm{a}}$ & $1.21^{\mathrm{a}}$ \\
10 & $238.73^{\mathrm{b}}$ & $218.73^{\mathrm{b}}$ & $0.94^{\mathrm{b}}$ & $1.07^{\mathrm{b}}$ \\
15 & $228.29^{\mathrm{b}}$ & $208.29^{\mathrm{b}}$ & $0.89^{\mathrm{b}}$ & $1.05^{\mathrm{b}}$ \\
Dietary protein: & & & & \\
25 & $248.82^{\mathrm{b}}$ & $228.82^{\mathrm{b}}$ & $0.99^{\mathrm{b}}$ & $1.08^{\mathrm{a}}$ \\
32 & $279.09^{\mathrm{a}}$ & $259.09^{\mathrm{a}}$ & $1.13^{\mathrm{a}}$ & $1.14^{\mathrm{a}}$ \\
Feeding frequency: & & & & \\
3 & $254.60^{\mathrm{b}}$ & $234.60^{\mathrm{a}}$ & $1.01^{\mathrm{a}}$ & $1.09^{\mathrm{a}}$ \\
6 & $273.31^{\mathrm{b}}$ & $253.31^{\mathrm{a}}$ & $1.11^{\mathrm{a}}$ & $1.13^{\mathrm{a}}$ \\
\hline
\end{tabular}

* Initial mean weight $20 \pm 5 \mathrm{~g}$.

a,b,c: means with different supersctipts differ significantly $(\mathrm{P}<0.05)$

The present study showed that the final weiglt. gain and average daily gain were significantly affected by increasing protein levels from $25 \% \mathrm{CP}$ to $32 \% \mathrm{CP}$, while the $32 \% \mathrm{CP}$ was the best for tilapia monosex reared in the pond. These results agreed with those found by Shaiu et al., 1987 in hybrid tilapia. For instance, estimales of 30\% (Wang et al., 1985), 30-35\% (Maized et al., 1979) were reported. Kono and Nose (1971) showed that frequency of feeding is apparently related, among other paramelers, to stomach size, since species will smaller stomaclis requirc more frequent fecding for maximum growth. The feeding frequency in the present study slowed that 6 times a day produced better growth than 3 times of day. Similar results were obtained by Kubryk (1980) who found that tilapia grew faster when fed four times daily than when fed two times, however, fish did not grow faster when fed eight times. There was a strong trend for both production and final harvests to increase with increasing stocking density. The results (Tabie 3) showed that the higher production was observed at $15 \mathrm{fish} / \mathrm{m}^{-2}$ (average $10554.73 \mathrm{~kg} /$ feddan) than for fish stocked at 5 or $10 \mathrm{fish} / \mathrm{m}^{-2}$ (average 5640.65 and $7785.37 \mathrm{~kg} /$ feddan respectively). These results agreed with those found by Cruze and Ridh (1991), when reared tilapia hybrid at differem densities. Also, Bjonsson (1994) found that total production increased with increasing stocking density within certain limits due to the fixed carrying capacity of the ccosystem under certain conditions.

\begin{tabular}{lcc}
\multicolumn{2}{l}{ Table 3. Main effects on final production and survival of mono sex tilapia reared in ponds } \\
\hline Main effect & $\begin{array}{c}\text { Production } \\
\text { Kg/feddan }\end{array}$ & $\begin{array}{c}\text { Survival } \\
\text { rate \% }\end{array}$ \\
\hline Stocking density & $5640.65^{\mathrm{c}}$ & $82.71^{\mathrm{a}}$ \\
5 & $7785.37^{\mathrm{b}}$ & $79.29^{\mathrm{b}}$ \\
10 & $10554.37^{\mathrm{a}}$ & $72.62^{\mathrm{c}}$ \\
15 & & \\
Dietary protein & $7794.22^{\mathrm{b}}$ & $81.79^{\mathrm{a}}$ \\
25 & $8192.95^{\mathrm{a}}$ & $74.62^{\mathrm{b}}$ \\
32 & & \\
Frequency of feeding & $7083.08^{\mathrm{b}}$ & $72.96^{\mathrm{a}}$ \\
3 & $9154.09^{\mathrm{a}}$ & $83.45^{\mathrm{b}}$ \\
6 & & $\cdot$
\end{tabular}


On the other hand, effect of different protein levels on production was observed since total production was significantly increased by increasing protein levels. Also, the effect of different frequency of feeding differed significantly. Survival rates were related to stocking density as might be expected. The results of the present study showed that survival was significantly affected by stocking density (average $82.71,79.29$ and $72.92 \%$ for 5,10 and 15 fish $\mathrm{m}^{-3}$, respectively).

Daungswasdi et al. (1986) reported that the survival rate of Nile tilapia raised in cage was not dependent upon stocking density. However, Haylor (1991) found that survival rate in African cat fish fry were directly related to stocking density.

On the other hand, protein levels and feeding frequency affected significantly survival, while increasing protein level or feeding frequency ( $32 \% \mathrm{CP}$ or 6 time/day) were better than the low protein level or feeding frequency. ( $25 \%$ and 3 lime/day).

In conclusion the present study showed that the 5 fish $\mathrm{m}^{-3}$ and $32 \% \mathrm{CP}$ and 6 time / day feeding frequency were better for tilapia monosex reared in ponds under the present experimental conditions.

\section{REFERENCES}

AOAC, 1984. Association of Official Analytical Chemists, Official Methods of Analysis $14^{\text {th }}$ ed., Association of Official Analytical Chemists, Arlington, Virginia, 1141 PP.

Brett J.R., 1973, Energy Expenditure of Sockeye Salon during sustained performance, J. Fish Res. Board Can. 30 (12/1) 1799-1800.

Cruz E.M. and Ridh, M., 1991. Production of the tilapia Oreochomis spilurus, Gunther stocked at different densities in sea cages, Aquaculture, 99:95-103.

Daungsawasdi, S., C. Choinclei, R. Yamorbsin and B. Kertkomut, 1986. Net cage culture of tilapia and puntius in klong praew irrigation tank, Tech. Pap. NIFI No. 64, Bangkhen, Bangkok, Thailand, $10 \mathrm{PP}$.

Duncan D.B., 1955. Multiple range and multiple "F" tests. Biometrics, 11:1-42.

F.A.O., 1980. Report of the ed hoc research : FAO Fish, Rep. 238, FAO, Rome, 26 PP.

Haylor G.S., 1991. Controlled hatchery production of Clarias gariepinus, growth and survival of fry at high stocking density, Aquacult, Fish, Manage, 23:303-314.

Hickling C.F., 1962. Fish culture faber and faber, London 317 PP.

Jauncey K., 1982. The effect of varying dietary protein levels on growlh, food conversion, protein utilization and body composition of juvenile tilapia, Aquaculture 27:43-54.

Kono H. and Y. Nose, 1971. Relationship between the amount of food taken and growth of fish, 1, Frequency of feeding for a maximum daily ration, Bull, Jap. Soc. Sci. Fish. 37:169-194.

Kubaryk J.M., 1980. Effect of diet feeding schedule and sex on food consumption, growth and retention of protein and energy by tilapia, Ph.D. Dissertation, Auburn, University, Auburn, Alabama, $51 \mathrm{PP}$.

Mazid M.A., Y. Tanaka, T. Katayama and C.O. Chichister, 1979. Growth response of (Tilapia zillii) fingerlings fed isocaloric diets with variable protein levels, Aquaculture 18:115-122.

SAS, 1988. SAS, User's Guide: Statistics version 5: SAS Institute, Cary, NC, 1028 PP.

Shell E.W., 1968. Monosex culture of male (Tilapia nioltica L) in ponds stocked at three rates, Proceeding of the world symposium on warm-water pond fish culture F.A.O. fish, Reports No. 44, Vol. 4, PP. 353-356.

Shiau S.Y., J.L. Chuang and C.L. Sun, 1987. Inclusion of soybean meal in tilapia diets at two protein levels, Aquaculture 65:251-261.

Van der Lingen M.I., 1967. Some preliminary remarks on stocking rate and production of tilapia species at the Fisheries Research, Center In. Proc. First Fisheries Day in Southern Rlodesia Gov. Printer Salisbury. PP. 54-68.

Wang K, Wei, T.Takeuchi, and T. Watanabe, 1985, Effect of dietary protein levels on growth of tilapia nilotica, Bull. Jpn. Soc. Sci., Fish. 5I:133-140.

Wohfarth G.W. and G. Hulalta, 1983. Applied Genetics of tilapias ICLARM, Studies and Reviews 6, International Center for Living Aquatic Research Mangement, Manila.

Zein-El-Dain Z. P. and S.P. Meyers, 1973. General consideration in problems in shrimp nutrition, Proc. World, Maricult, Soc., 4:299.

Zonneveld N., and R. Fadhali, 1991. Feed intake and growth of red tilapia at different stocking densities in ponds in Indonesia, Aquaculture 99:83-94. 